Sol Ventrikül Sistolik Fonksiyonu Korunmuş Koroner Arter

Hastalarında Koenzim Q10 Düzeyi ile Diyastolik Disfonksiyon iliş̧kisi

\title{
The Relationship Between Coenzyme Q10 Level and Diastolic Dysfunction in Coronary Artery Disease Patients with Preserved Left Ventricular Systolic Function
}

Bernas Altıntaș, Erkan Baysal, Rojhat Altındağ, Önder Bilge

Sağlık Bilimleri Üniversitesi, Gazi Yaşargil Eğitim ve Araştırma Hastanesi, Kardiyoloji Kliniği, Diyarbakır, Türkiye

\section{$\ddot{O} Z$}

GíRiŞ ve AMAÇ: Bu çalışmanın amacı, sol ventrikül sistolik fonksiyonları korunmuş koroner arter hastalı̆̆ $(K A H)$ olan hastalarda, sol ventrikül diyastolik fonksiyonları ile koenzim Q10 seviyesi arasındaki ilişkiyi araştırmaktır.

YÖNTEM ve GEREÇLER: Temmuz ve Ekim 2009 tarihleri arasinda koroner anjiyografi uygulanan ve anlamlı KAH tanisl koyulan 20 ve 86 yaşları arasındaki 64 hasta çalışmaya dahil edildi. Hastalar, sol ventrikül diyastolik disfonksiyonunun varlığl ve yokluğuna göre iki gruba ayrıldı.

BULGULAR: Çalışmaya toplam 64 önemli KAH hastası dahil edildi; Çalışma hastalarının 42' si(\% 65.6) erkek cinsiyette hastalar oluşturdu. Ortalama yaş $60.5 \pm 12.1$ yll olarak tespit edildi. Tüm hastalarda ortalama plazma koenzim Q10 düzeyi $1408.2 \pm 346.5 \mu \mathrm{g} /$ L. Gruplar Koenzim Q10 düzeyleri göre karşılaştırıldığında, sol ventrikül diyastolik disfonksiyonu olan grupta Koenzim Q10 düzeyi $1516.0 \pm 381.0 \mu \mathrm{g} / \mathrm{L}$, sol ventrikül diyastolik disfonksiyonu bulunmayan grupta ise $1285.7 \pm 472.6 \mu \mathrm{g} / L$ olarak tespit edildi $(p=0.08)$.

TARTISSMA ve SONUÇ: Sistolik fonksiyonları korunmuş olan anlamlı $K A H$ varliğında sol ventrikül diyastolik disfonksiyonu ile koenzim Q10 seviyeleri arasında anlamlı bir ilişki gözlenmedi.

Anahtar Kelimeler: koroner arter hastalı̆̆l, koenzim Q10, diyastolik disfonksiyon

\section{ABSTRACT}

INTRODUCTION: The aim of this study was to investigate the relationship between left ventricular diastolic functions and coenzyme Q10 levels in coronary artery disease $(C A D)$ patients with preserved left ventricular systolic functions.

METHODS: A total of 64 patients aged between 20 and 86 years, in whom coronary angiography were performed and documented significant $C A D$, were included in the study between July and October 2009. The patients were classified into two groups based on the presence and absence Left ventricular diastolic dysfunction (LVDD).

RESULTS: A total of 64 significant CAD patients were included in the study, of whom $42(65.6 \%)$ were male. The mean age was $60.5 \pm 12.1$ years. The mean plasma coenzyme $Q 10$ level in all patients was $1408.2 \pm 346.5 \mu \mathrm{g} / \mathrm{L}$. The groups were compared for coenzyme $Q 10$ levels, which were found to be $1516.0 \pm 381.0 \mu \mathrm{g} / L$ in the presence of $L V D D(+)$ and $1285.7 \pm 472.6 \mu \mathrm{g} / L$ in the absence of LVDD group $(p=0.08)$.

DISCUSSION and CONCLUSION: A significant relationship was not observed between LVDD and coenzyme Q10 levels in the presence of significant $C A D$ with preserved systolic functions.

Keywords: coronary artery disease, coenzyme Q10, diastolic dysfunction 


\section{INTRODUCTION}

Coenzyme Q10 was first isolated from bovine heart mitochondria by Dr. Frederick Crane in 1957. In 1958, Dr. Karl Folkers and his assistant Merck determined the chemical structure of coenzyme Q10 and synthesized it by fermentation for the first time (1). Coenzyme Q10, also known as ubiquinone, is a lipophilic and lipoprotein-transported vitamin-like quinone that is produced endogenously by the same pathway with cholesterol in all cells where HMG CoA reductase enzyme is effective (2). Because of the key role of coenzyme Q10 in mitochondrial oxidative phosphorylation, which is an essential source of ATP in tissues such as myocardium that have a high energy requirement, and its antioxidant activity preventing LDL-cholesterol oxidation which is an important step in lipid peroxidation, NO oxidation, and atherosclerosis development, its role in heart diseases has been a field of research (3-5). The diastolic functions of the heart are high energy requiring processes. Coronary heart disease, which may lead to changes in myocardial cell energy metabolism and cause increase in oxidative stress, is known to impact diastolic functions

The relationship between coenzyme Q10 and left ventricular diastolic dysfunction (LVDD) has been studied in diastolic heart failure due to hypertrophic cardiomyopathy (HCM), hypertension, diabetes mellitus and statin therapy and yielded contradictory results (6-9). While there are publications about the relationship of plasma coenzyme Q10 with only LVDD or only IHD in the literature, there are no studies investigating the relationship between plasma coenzyme Q10 deficiency that occurs in significant coronary artery disease (CAD) with LVDD. The aim of this study was to investigate the relationship between plasma coenzyme Q10 levels and LVDD in CAD patients with preserved left ventricular systolic functions.

\section{METHODS}

\section{Study population}

Acil A total of 74 patients aged between 20 and 86 years, in whom coronary angiography due to Class 3A stable angina pectoris or low-risk unstable AP were performed and documented significant CAD, were included in the study between July and October 2009. Patients with valvular heart disease, arrhythmia, acute myocardial infarction, heart failure, severe liver and kidney disorders and chest pain of non-cardiac causes, and patients on statins were excluded. After the exclusion 64 patients were included study. Informed consent was obtained from all patients included in the study. The study protocol was approved by the local ethics committee and conforms to the Declaration of Helsinki (10)

\section{Coronary angiography}

Coronary angiography was conducted through femoral artery by the Judkins technique without using nitroglycerin, adenosine or a calcium channel blocker. Angiograms were recorded at 25 frames/sec rate using DICOM digital media devices, and were evaluated by two cardiologists blinded to the clinical information of the patients. Significant CAD was defined as more than $70 \%$ narrowing in the diameter of any major coronary artery, including large diagonal and obtus marginal side branches ( Diameter $>2.5 \mathrm{~mm}$ ).

\section{Echocardiography}

Echocardiographic measurements were conducted within the first 24 hours following coronary angiography via a Hewlett-Packard imaging system echocardiography device using a $2.5 \mathrm{mHz}$ transducer (Agillent Sonos 4500 Andover, MA). All patients underwent standard twodimensional echocardiography, colored Doppler imaging, and mitral annulus tissue measurements via continuous and intermittent Doppler flow. The measurements were made according to the recommendations of American Society of Echocardiography (11).

Standard Doppler flow: Early mitral diastolic flow velocity $(\mathrm{Em})$, late mitral diastolic flow velocity $(\mathrm{Am}), \mathrm{Em} / \mathrm{Am}$ ratio, and early mitral diastolic flow deceleration time (DTm) were obtained. In order to determine DTm, the time between the peak and the baseline of the $\mathrm{E}$ wave was measured. Mitral valve $\mathrm{E}$ and $\mathrm{A}$ wave velocities were measured to calculate the E/A ratio.

Tissue Doppler imaging (TDI) echocardiography: The measurements were made by placing the $5 \mathrm{~mm}$ tissue Doppler volume sample on the septal and lateral ends of the mitral annulus, 
in the apical four-chamber view. Peak early diastolic relaxation velocity of the mitral annulus $\left(E^{\prime} m\right)$, peak late diastolic relaxation velocity of the mitral annulus (A'm), and peak systolic flow velocity of the mitral annulus ( $S^{\prime} m$ ) velocities where measured at the annulus levels on septal and lateral walls, and average values were obtained.

\section{Left Ventricular Diastolic dysfunction (LVDD) criteria}

Impaired relaxation; $(\mathrm{E} / \mathrm{A}) \mathrm{m}$ ratio $<1, \mathrm{DTm}>220$ msec, IVRT $\geq 100 \mathrm{msec}$.

Pseudonormalized; (E/A)m ratio > 1, DTm $=160$ $200 \mathrm{msec}$ and IVRT $<100 \mathrm{msec}$ and E/A ratio with Valsalva $<1$.

Restrictive filling; (E/A)m ratio $\geq 2$, DT $<160 \mathrm{msec}$ and IVRT $\leq 60 \mathrm{msec}$ and E/A ratio with Valsalva $<1$.

Tissue Doppler; (E'/A')m $<1$, septal E' $\mathrm{m}<8 \mathrm{~cm} / \mathrm{sec}$, the lateral $E^{\prime} \mathrm{m}<12 \mathrm{~cm} / \mathrm{sec}$ and average E'm $<10$ were also considered to be LVDD (12).

\section{Biochemical analysis}

Blood samples were collected prior to coronary angiography. Complete blood count, biochemical and lipid parameters were studied from these samples. After the last patient was recruited, calibrator level-1 and level-2 were loaded to the High Performance Liquid Chromatography device (HPLC; Agilent Technologies CA, USA) prior to the CoQ10 level measurements. The measurement procedure was initiated after the device was validated by the standard measurements. Precipitation process was applied to the serum samples before storage. they were centrifuged at $1200 \mathrm{rrpm}$ and stored at $-80{ }^{\circ} \mathrm{C}$ until analysis. Coenzyme Q10 plasma/serum Chromsystems reagents was used in the HPLC device. The Ultra Violet detector wave-length of the device was 275 $\mathrm{nm}$, colon heat was ambient $\left(\sim 25{ }^{\circ} \mathrm{C}\right)$, injection volume was $50 \mu \mathrm{l}$, and flow rate was $2.5 \mathrm{~mL} / \mathrm{min}$. Duration of the analysis was 14 minutes in this study and the coenzyme Q10 peak was attained around 10-12th minutes. The results were presented in comparison to the standard curve values, as $\mu \mathrm{g} / \mathrm{L}$ (or $\mathrm{nmol} / \mathrm{mL}$ ).

\section{Statistical analysis}

All statistical analyses were performed using the IBM SPSS software (IBM SPSS Statistics for Windows, Version 16.0. Armonk, NY: IBM Corp.). While the categorical variables were presented as percentages, numerical values were calculated as mean \pm standard deviation (SD). In the comparisons, Student's t-test was used for normally distributed and Mann-Whitney U test was used for non-normally distributed numerical variables. In the comparisons of different groups in terms of categorical variables, Chi-Square test was used. $\mathrm{P}$ values $<0.05$ was considered significant in all analyses. For correlation analyses, Pearson Correlation Test were used to determine associations between two variables.

\section{RESULTS}

There were 64 patients included in the study, of whom $42(65.6 \%)$ were males. The mean age was $60.5 \pm 12.1$ years. There was history of hypertension in $31(48.4 \%)$, diabetes mellitus in $13(20.3 \%)$, smoking in $23(35.9 \%)$ of the patients. The mean plasma coenzyme Q10 level was $1408 \pm 346 \mu \mathrm{g} / \mathrm{L}$. The patients were classified into two groups based on presence of LVDD (33 patients, 51.5\%) and absence LVDD (31 patients, $48.5 \%$ ). There were no statistical differences between the groups with regard to baseline clinical characteristics and laboratory parameters (Table 1-2).

\begin{tabular}{|c|c|c|c|}
\hline Variables & $\begin{array}{c}\text { Absence of } \\
\text { LVDD } \\
(n=31)\end{array}$ & $\begin{array}{l}\text { Presence of } \\
\qquad \begin{array}{c}\text { LVDD } \\
(n=33)\end{array}\end{array}$ & $p$ value \\
\hline Age (years) & $58.2 \pm 13.2$ & $62.9 \pm 11.1$ & 0.19 \\
\hline Male sex (n, \%) & $20(64.5 \%)$ & $22(66.6 \%)$ & 0.46 \\
\hline $\begin{array}{r}\text { Hypertension } \\
(n, \%)\end{array}$ & $14(45.1 \%)$ & $17(51.5 \%)$ & 0.14 \\
\hline $\begin{array}{r}\text { Diabetes } \\
\text { mellitus (n, \%) }\end{array}$ & $6(19.3 \%)$ & $7(21.2 \%)$ & 0,68 \\
\hline Smoking (n, \%) & $11(35.4 \%)$ & $12(36.3 \%)$ & 0.72 \\
\hline $\begin{array}{l}\text { Family history } \\
\text { of CAD }(n, \%)\end{array}$ & $7(22.5)$ & $8(24.2)$ & 0.70 \\
\hline $\begin{array}{r}\text { Hyperlipidemia } \\
(\mathrm{n}, \%)\end{array}$ & $8(25.8)$ & $9(27.2)$ & 0.56 \\
\hline $\begin{array}{l}\text { Data are } \\
\text { distributed da } \\
\text { variables; } C A \\
\text { ventricular di }\end{array}$ & $\begin{array}{l}\text { ressed as } \\
\text { or count } \\
\text { Coronary } \\
\text { olic dysfun }\end{array}$ & $\begin{array}{l}\text { eant SD } \\
\text { centage) } \\
\text { ery diseas } \\
n\end{array}$ & $\begin{array}{l}\text { normaly } \\
\text { tegorica } \\
D D, \text { Left }\end{array}$ \\
\hline
\end{tabular}




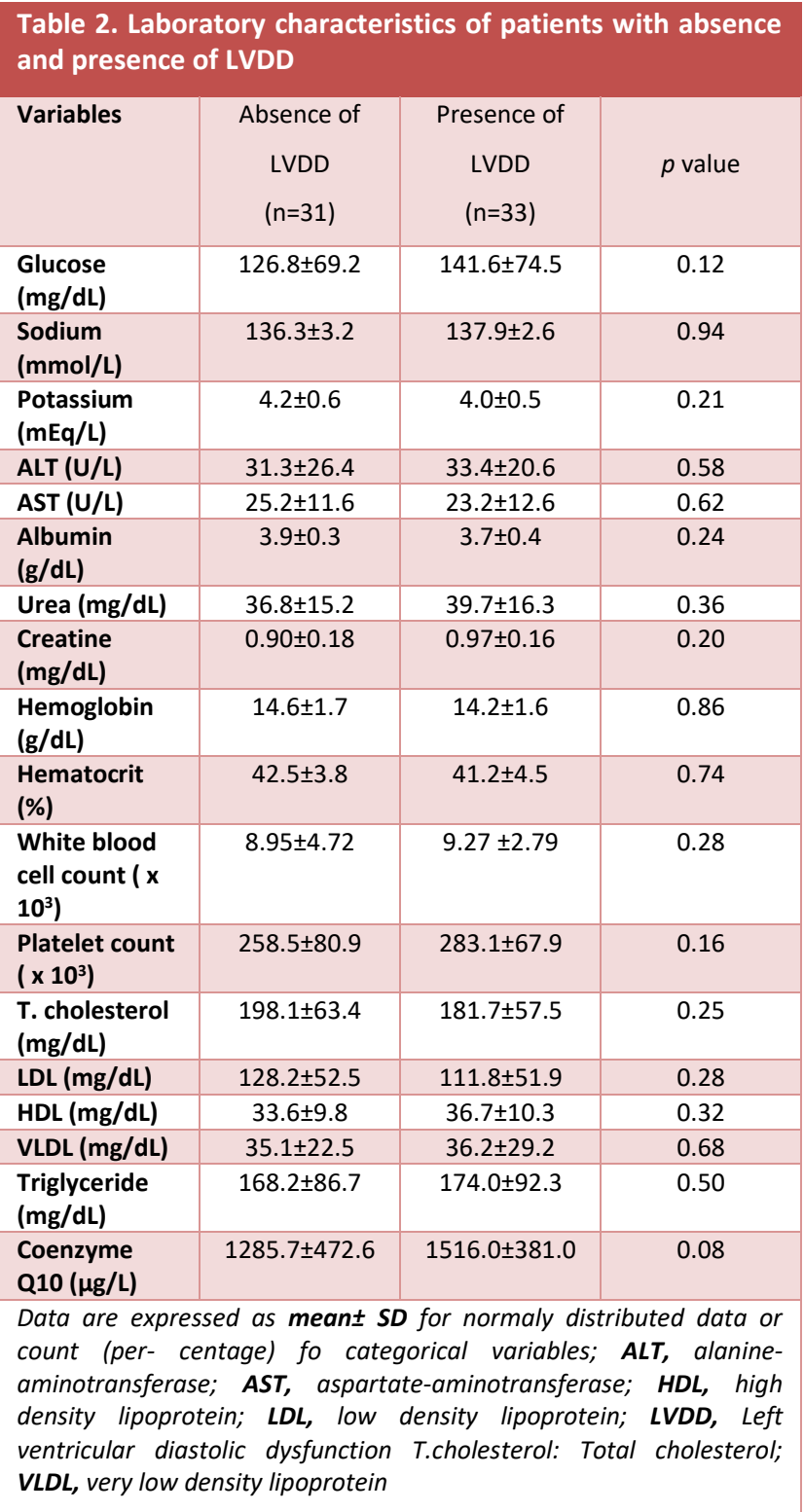

The groups were compared in terms of their mean coenzyme Q10 levels, which were 1516.0 \pm 381.0 $\mu \mathrm{g} / \mathrm{L}$ in the presence of LVDD and $1285.7 \pm 472.6 \mu \mathrm{g} / \mathrm{L}$ in the absence of LVDD. No statistical significant difference was detected between the groups $(\mathrm{p}=0.08)$. Increased interventricular septum diastolic diameter (IVSdd), left atrium diastolic diameter (LA dd), DTm, Am, $A^{\prime} m$ and decreased Em, E'm, early mitral diastolic flow velocity/late mitral diastolic flow velocity ratio $(\mathrm{Em} / \mathrm{Am})$ and early mitral diastolic flow velocity/peak early diastolic relaxation velocity of the mitral annulus ratio $(\mathrm{Em} / \mathrm{E} \cdot \mathrm{m})$ were observed with statistical difference in patients with LVDD than those without LVDD (Table 3).
Tablo 3. Echocardiographic characteristics of patients with absence and presence of LVDD

\begin{tabular}{|l|c|c|c|}
\hline Variables & $\begin{array}{c}\text { Absence of } \\
\text { LVDD } \\
(\mathrm{n}=31)\end{array}$ & $\begin{array}{c}\text { Presence of } \\
\text { LVDD } \\
(\mathrm{n}=33)\end{array}$ & $p$ value \\
\hline IVS dd (cm) & $1.12 \pm 0.11$ & $1.23 \pm 0.14$ & 0.03 \\
\hline IVS sd (cm) & $1.57 \pm 0.17$ & $1.63 \pm 0.16$ & 0.26 \\
\hline LV dd (cm) & $5.23 \pm 0.63$ & $5.05 \pm 0.51$ & 0.18 \\
\hline LV sd (cm) & $3.54 \pm 0.60$ & $3.48 \pm 0.58$ & 0.64 \\
\hline LA dd (cm) & $3.32 \pm 0.43$ & $3.84 \pm 0.41$ & 0.04 \\
\hline LVEF (\%) & $52.8 \pm 11.7$ & $50.1 \pm 9.4$ & 0.55 \\
\hline LVFS (\%) & $27.2 \pm 6.4$ & $26.1 \pm 6.1$ & 0.78 \\
\hline Em (cm/sn) & $122.5 \pm 38.4$ & $86.4 \pm 41.3$ & 0.02 \\
\hline Am (cm/sn) & $96.8 \pm 24.7$ & $118.2 \pm 32.9$ & 0.03 \\
\hline (E/A)m & $1.27 \pm 1.5$ & $0.72 \pm 1.2$ & 0.01 \\
\hline DTm (msn) & $187 \pm 49$ & $296 \pm 45$ & 0.01 \\
\hline (E')m & $11.4 \pm 3.6$ & $9.2 \pm 2.8$ & 0.03 \\
\hline (A')m & $8.5 \pm 3.9$ & $10.6 \pm 3.3$ & 0.04 \\
\hline Sm (cm/sn) & $11.2 \pm 3.1$ & $10.9 \pm 3.9$ & 0.82 \\
\hline (E/E')m & $10.7 \pm 3.4$ & $9.2 \pm 1.6$ & 0.04 \\
\hline Data $\mathbf{m}$ (cm & & \\
\hline
\end{tabular}

Data are expressed as mean \pm SD for normaly distributed data or count (per- centage) fo categorical variables; Am, late mitral diastolic flow velocity; A'm, peak late diastolic relaxation velocity of the mitral annulus (tissue Doppler); dd, diastolic diameter; (DT)m, early mitral diastolic flow deceleration time, Em, early mitral diastolic flow velocity; E'm, peak early diastolic relaxation velocity of the mitral annulus (tissue Doppler); (E/A) m, early mitral diastolic flow velocity /late mitral diastolic flow velocity; IVS, Interventricular septum; LV, Left ventricle, LVEF; left ventricular ejection fraction, LVFS; Left ventricular fractional shortening; LA, left atrium; sd, systolic diameter, Sm, systolic flow velocity across mitral annulus (tissue Doppler);

\section{DISCUSSION}

The aim of this study was to investigate the relationship between LVDD and coenzyme Q10 deficiency that develop in significant CAD patients with preserved left ventricular systolic functions, which has not been studied before, to the best of our knowledge. The mean plasma coenzyme Q10 level of patients included in the study who had significant $\mathrm{CAD}$ with no systolic dysfunction were similar to that of healthy individuals, reported in the literature. These results are not consistent with the prior studies conducted in CAD patients $(13,14)$.

There are other factors that impact plasma coenzyme Q10 levels that may have caused this result. The first one is exogenous, dietary intake. When maintenance of plasma coenzyme Q10 levels is considered, $50 \%$ is provided via dietary intake and the remaining $50 \%$ is synthesized endogenously (15). Another factor that impacts plasma coenzyme Q10 levels is interracial differences. A 2002 publication compared CAD 
predisposition and inter-population coenzyme Q10 levels and reported that the coenzyme Q10 levels were significantly lower in Indians predisposed to CAD, especially males, compared to Chinese (16). Another factor impacting the plasma coenzyme Q10 levels is the balance of oxidized (ubiquinone) and reduced (ubiquinol) forms in the plasma. The ubiquinone/ubiquinol ratio is named as coenzyme Q10 redox ratio in the medical literature $(17,18)$. In cardiovascular diseases, especially coronary heart disease, oxidative stress increases while coenzyme Q10 redox ratio decreases in cases like diabetes mellitus and cancer $(19,20)$. The studies in the literature that investigated the relationship between age and coenzyme Q10 level did not showed a significant association $(21,22)$. In our study an association between age and plasma coenzyme Q10 level was not observed which is consistent with the literature.

The relationship between coenzyme Q10 and DD has been studied in cases with diastolic heart failure related with HCM. In a 2007 study by Kumar et al, $46 \mathrm{HCM}$ patients were administered coenzyme Q10 for 14.5 months at $200 \mathrm{mg} /$ day dose and at the end of the study, the patients had improvement in at least one of their LVDD parameters (23).

Another field of research is patients on statin treatment. Statins are known to reduce coenzyme Q10 synthesis that shares the mevolanate pathway with cholesterol by inhibiting 3-hydroxy-3-methylglutaryl-coenzyme A (HMG-CoA) reductase. The reversal of impact of statin use by coenzyme Q10 supplementation in systolic heart failure where energy depletion plays a role has been previously investigated (24). A study published in 2003 reported that statin therapy induces LVDD in individuals who initially had normal cardiac functions (25). Another study published in 2004 reported that patients with impaired diastolic parameters following atorvastatin therapy, had improved parameters after oral coenzyme Q10 administration (26).

In a 2008 study, fenofibrate and coenzyme Q10 were administered separately and in combination to type 2 diabetic and LVDD patients. However none of the groups demonstrated a significant change in diastolic parameters by the end of the study (27). In another study, three patient groups with hypertension, mitral valve prolapsus (MVP) and Chronic Fatigue Syndrome were administered coenzyme Q10 and their diastolic functions were investigated and likewise, no significant improvement was observed in the diastolic parameters (8). While studies have conflicting results, an association is suspected between LVDD and coenzyme Q10 due to plausible pathophysiological mechanisms.

Our study, which was designed to demonstrate the association between coenzyme Q10 and DD in the presence of significant CAD failed to determine a statistically significant difference between the groups with and without $\mathrm{DD}$, although, on the contrary, higher levels of coenzyme Q10 were detected among patients with DD. Although plasma coenzyme Q10 levels have been reported to be low in LVDD patients with HCM, other types of cardiomyopathy with systolic dysfunction and in LVDD patients on statin therapy which directly impacts coenzyme Q10 synthesis, similar results have not been obtained among LVDD patients with hypertension, MVP, and diabetes mellitus. An important characteristic of the patients in the groups that did not benefit from coenzyme Q10 was that these patients did not have systolic function loss and did not have cardiac remodeling in myocardial tissue. The significant CAD patients included in the study had preserved EF and impaired relaxation constituted majority of their LVDD. Moreover, these were patients with mild LVDD who did not have maladaptive remodeling or systolic dysfunction. The oxidative and reduced forms of coenzyme Q10, which plays an important role in energy metabolism in plasma in case of increased oxidative stress and energy need, were not measured in this study and it is not clear how they are affected. Nevertheless we suggest that the measured high total plasma coenzyme Q10 level in our study is more likely to be caused by high ubiquinone (oxidized form) levels.

\section{STUDY LIMITATIONS}

The limited number of coenzyme Q10 kits limited the sample size of this study. Therefore, lack of subgroups based on DD stages and evaluation of the association between coenzyme 
Q10 level and DD stages is the major limitation of the study. Another limitation is that the total plasma coenzyme Q10 level but not the individual levels of the oxidized (ubiquinone) and reduced (ubiquinol) forms, were measured.

\section{CONCLUSION}

A significant relationship was not identified between plasma coenzyme Q10 level and LVDD in CAD patients with preserved left ventricular systolic functions. This may be possibly due to our study was not include CAD patients with advanced diastolic dysfunction which were generally accompained by maladaptive cardiac remodelling. In this regard further larger-scale studies that include different LVDD stages with differing severities of cardiac remodeling may be required in order to determine whether coenzyme Q10 deficiency occurs in the presence of CAD.

\section{REFERENCES}

1. Othman 1.Pepe S, Marasco SF, Haas SJ, Sheeran FL, Krum H, Rosenfeldt FL. Coenzyme Q 10 in cardiovascular disease. Mitochondrion. 2007 Jun;7 Suppl: S154-67.

2. Molyneux SL, Florkowski CM, Lever M, George PM. Biological variation of coenzyme Q10. ClinChem 2005;51:455-7.

3. Turunen M, Olsson J, Dallner G. Metabolism and function of coenzyme Q,Biochimica et BiophysicaActa (BBA) - Biomembranes, Volume 1660, Issue 1-2, January 2004, Pages 171-99.

4. Crane FL ve ark. Biochemical Functions of Coenzyme Q10, Journal of the American College of Nutrition 2001; 20: 591-8.

5. Ito H, Nakajima T, Takikawa R, Hamada E, Iguchi $M$, Sugimoto $T$ et al. Coenzyme Q10 attenuates cyanide activation of the ATP-sensitive $\mathrm{K}+$ channel current in single cardiac myocytes of the guinea-pig. NaunynSchmiedebergs Arch Pharmacol. 1991;344:133-6.

6. Huynh K, Kiriazis H, Du XJ, Love JE, Jandeleit-Dahm KA, Forbes JM et al.Coenzyme Q10 attenuates diastolic dysfunctions, cardiomyocyte and cardiac fibrosis in the $\mathrm{db} / \mathrm{db}$ mause model of tpe 2 diabetes. Diabetologia. 2012 May;55:1544-53.

7. Kumar A, Kaur H, Devi P, Mohan V (2009) Role of coenzyme Q10 (CoQ10) in cardiac disease, hypertension and Meniere-like syndrome. Pharmacol Ther 124:259-68
8. Langsjoen, P. H., \& Folkers, K. (1993). Isolated diastolic dysfunction of the myocardium and its response to CoQ10 treatment. ClinInvestig 71(8 Suppl), S140-4

9. Langsjoen PH, Langsjoen A, Willis R, Folkers K. Treatment of hypertrophic cardiomyopathy with coenzyme Q10. Mol Aspects Med. 1997;18 Suppl:S145-51.

10. Rickham PP. Human Experimentation. Code of Ethics of the World Medical Association. Declaration of Helsinki. Br Med J.1964;2:177

11. Quiñones MA, Otto CM, Stoddard M, Waggoner A, Zoghbi WA; Doppler Quantification Task Force of the Nomenclature and Standards Committee of theAmerican Society of Echocardiography. Recommendations for quantification of Doppler echocardiography: a report from the Doppler Quantification Task Force of the Nomenclature and Standards Committee of the American Society of Echocardiography. J Am SocEchocardiogr. 2002 Feb;15:167-84.

12. Nagueh SF, Appleton CP, Gillebert TC, Marino PN, Oh JK, Smiseth OA et al. Recommendations for the evaluation of left ventricular diastolic function by echocardiography. J Am Soc Echocardiogr. 2009 Feb;22:107-33.

13. Van Jaarsveld H, Potgeiter GM, Loschner A. Changes in NADH-coenzyme Q10 reductase (complex I) with autolysis in the rat heart as experimental model. Enzyme. 1986;35:206-14.

14. Folkers, K, Littarru G. P, Ho L, Runge T. M, Havanonda S, \& Cooley D. (1970). Evidence for a deficiency of coenzyme Q10 in human heart disease. Int J VitamNutr Res 40, 380-90.

15. Mabuchi H, Nohara A, Kobayashi J, Kawashiri MA, Katsuda S, Inazu A et al; Hokuriku Lipid Research Group. Effects of CoQ10 supplementation on plasma lipoprotein lipid, CoQ10 and liver and muscle enzyme levels in hypercholesterolemic patients treated with atorvastatin: a randomized double-blind study. Atherosclerosis. 2007 Dec;195:182-9.

16. Hughes K, Lee BL, Feng X, Lee J, Ong $\mathrm{CN}$. Coenzyme Q10 and differnces in coronary heart disease risk in Asian Indians and Chinese. Free RadicBiol Med. 2002 Jan 15;32:132-8.

17. Lagendijk J, Ubbink JB, Vermaak WJ. Measurement of the ratio between the reduced and oxidized forms of coenzyme Q10 in human plasma as a possible marker of oxidative stres. J Lipid Res 1996;37:67-75. 
18. Yamashita S, Yamamoto Y. Simultaneous detection of ubiquinol and ubiquinone in human plasma as a marker of oxidative stres. Anal Biochem 1997;250:66-73.

19. Lagendijk J, Ubbink JB, Delport R, Vermaak WJ, Human JA. Ubiquinol/ubiquinon ratio as marker of oxidative stres in coronary artery disease. ResCommunMolPatholPharmacol. 1997 Jan;95:11-20.

20. Ruiz-Jiménez J, Priego-Capote F, MataGranados JM, Quesada JM, Luque de Castro MD. Determination of the ubiquinol-10 (coenzyme Q10) in human serum by liquid chromatography tandem mass spectrometry to evaluate the oxidative stress. J Chromatogr A. 2007 Dec 21;1175:242-8.

21. Miles MV, Horn PS, Morrison JA, Tang PH, DeGrauw T, Pesce AJ. Plazma CoQ10 refernce intervals, but not redox status, are affected by Gender and race in self-reported healthy adults. ClinChimActa 2003;332:123-32.

22. Miles MV, Horn PS, Tang PH, Morrison JA, Miles L, DeGrauw T et al. Age-related changes in plasma coenzyme Q10 concentrations and redox state in apparently healhy children and adults. ClinChimActa 2004;347:139-44.

23. Kumar A, Kaur H \& Mohan V (2007). Coenzyme Q10 in isolated diastolic heart failure in hypertrophic cardiomyopathy (HCM). The 5th Conference of the International Coenzyme Q10 Association, Kobe Japan.

24. Ghirlanda G, Oradei A, Manto A, Lippa S, Uccioli L, Caputo S, et al. (1993). Evidence of plasma CoQ10-lowering effect by HMG-CoA reductase inhibitors: a double blind, placebocontrolled study. Clin Pharmocol J 33: 226-9.

25. Silver MA \&Langsjoen PH (2003). Statin cardiomyopathy: a potential role for coenzyme Q10 therapy for statin induced changes in diastolic LV performance: description of a clinical protocol. Bio factors 18(1-4), 125-7.

26. Silver MA, Langsjoen PH, Szabo S, Patil $\mathrm{H}$, Zelinger A. Effect of atorvastatin on left ventricular diastolic function and ability of coenzyme Q10 to reverse that dysfunction. Am J Cardiol. 2004 Nov 15;94:1306-10.

27. Chew GT, Watts GF, Davis TM, Stuckey BG, Beilin LJ, Thompson PL et al. Hemodynamic effects of fenofibrate and coenzyme Q10 in type 2 diabetics subjects with left ventricular diastolic dysfunctions. Diabetes Care. 2008 Aug;31:1502-9. 